\title{
PERFORMANCE CHARACTERISTICS OF HIGH-EARNING MINORITY BANKS
}

\author{
Bruce J. Summers and James F. Tucker*
}

One of the interesting developments on the American banking scene during the post-World War II era has been the increased interest shown by minority groups in the ownership and operation of commercial banks. Of the 81 minority banks in existence at year-end 1975, only 8 were operating in 1945. Fifteen more opened between 1946 and 1969, while 58 date from 1970. Although there were only 81 minority banks among the 14,600 commercial banks in operation at the close of 1975 , the net increase in minority banks since the beginning of this decade amounts to over 250 percent, while the increase for nonminority banks amounts to only 12 percent. Of the 81 banks identified as minority institutions, 47 were owned by blacks and 27 were classified as HispanicAmerican, with the remainder being distributed among Chinese-American (3), American Indian (2), Asian-American (1), and Multiracial (1) minority groups. Two of these 81 banks were actually organized as nonminority banks, but were later taken over by minority interests. ${ }^{1}$

The sudden proliferation in minority-owned banking institutions has attracted considerable attention, largely because the financial and economic aspects of minority banking are recognized as unique in the industry. These organizations provide banking services primarily to the nation's minority population, and the special business circumstances they face are related to the special position occupied by minority groups in the national economy. The close tie between the economic position of blacks and the operation of

* The authors are grateful to Richard Rosenbloom and Peggy Nuckols for computational assistance. Jacqueline McDaniel, Data Base Analyst in the Division of Research and Governors of the Federal Reserve System, coordinated and supplied source data.

A bank is recognized as minority-owned when 50 percent or more of its common stock is owned or controlled by individuals belonging to racial minority groups. OMBE of the Commerce Department, and the Treasury Department, which is responsible for administration of the Government's Minority Bank Deposit Program, officially designate minority banks. A recent amendment to the rules governing the Minority Bank Deposit Program allows a bank to qualify if: more than 50 percent of the bank's stock is owned by women; it majority of the bank's board consists of women; and women hold a significant number of management positions. black banks, for example, is made by Brimmer $[7 ;$ p. 382]. Nevertheless, it is also true that a great deal of variability exists within the ranks of minority banks when it comes to successfully dealing with these unique business circumstances. The primary objective of this study is to analyze those factors that lie behind the successful operation of minority banks.

There are, no doubt, many reasons for the sharp acceleration in the establishment of minority banks during the 1970's. Based on interviews with persons instrumental in organizing a number of these banks, however, three factors emerge as being central to the decision-making process leading to application for a bank charter. The first of these involves an increased awareness by minority group entrepreneurs of the profitability of commercial banking. Indeed, the success of existing minority banks became widely publicized during the late 1960's and early 1970's, and there was reason to believe that economic advances being made by minorities provided an even more advantageous market for banking services. The second factor concerns the improved environment for seeking and obtaining bank charters. Doubtlessly a part of the change in this environment reflected the momentum of civil rights legislation passed during the middle and late $1960^{\prime}$ 's. Likewise, this was the period when minority groups began to achieve greater political influence at both the state and national levels, and this influence, at times, proved effective in "opening the door" to the chartering agencies and breaking bottlenecks for charter applications previously submitted. The third factor focuses on the then growing belief that locally-owned commercial banks could provide a stimulus to economic development in the minority community. Although some have questioned the ability of minority banks to perform this function successfully (see Brimmer [ 7 ; p. 399]), organizers of minority banks did in fact envision a significant role for their institutions in the development of minority business enterprise. 
The operating characteristics of minority-owned banks have been the focus of a number of studies $[2,3,4,5,6,7,8,11,13,14]$. Most studies of minority bank financial performance have considered bank operating characteristics in a comparative context. Using this methodology, minority banks have usually been compared to some other group of banks consisting of nonminority institutions, sometimes taking the form of all commercial banks or all nonminority banks. Brimmer [7], for example, compares the performance of black banks with that of all insured commercial banks and all member banks of the Federal Reserve System.

Other studies have also followed the relative performance methodology but have been more selective in choosing comparative sample groups of banks. In a companion to the Brimmer article mentioned above, Irons [11] views the operating characteristics of 18 black banks against a paired sample of 20 nonminority banks and a national average of similarly sized banks. Kohn [13] compares the performance of 6 minority banks ( 5 of which are located in the Tenth and 1 in the Eighth Federal Reserve District) with that of two groups of nonminority banks: 43 established member banks and 32 new commercial banks, all located in the Tenth Federal Reserve District. Boorman [2] and Boorman and Kwast [4] compare 8 minority banks established between 1963 and 1965 with a paired sample of nonminority banks. These two articles isolate the behavior of newly formed banks.

There are, of course, widely recognized problems with aggregating together all minority banks, or for that matter all commercial banks, for comparative purposes. Even when adjusted by size, age of operation, and location, it is difficult to get a meaningful sample group for comparing the operating characteristics of minority and nonminority banks. This is due to minority and nonminority banks serving communities that are quite different in terms of their social and economic makeup. It would seem, therefore, that there is something to be said for intragroup comparisons of minority banks.

Limited intragroup comparisons of minority banks have been made, notably as part of studies by Leavitt [14] and Boorman [3]. In these studies, both authors attempt to distinguish between newly formed and mature minority banks. Leavitt deals exclusively with black banks and constructs test groups on the basis of age (all black banks three years old versus all black banks over three years old) and charter classification (national and state-insured black banks). Boorman makes the most serious attempt at overcoming the problems associated with intergroup bank comparisons, but his discussion is limited to citing the differences between the newer and older minority banks. Perhaps most importantly, Boorman explicitly recognizes [3; p. 278] that ". . other factors indicate that there may be significant differences in performance among the minority banks themselves." It is this central idea-that performance comparisons of minority banks can be most useful when made with other minority banks-that lies at the base of this study.

Segmenting Minority Banks For Comparison This article undertakes an intragroup comparison of minority bank performance characteristics. Groups are identified for comparison from all minority-owned commercial banks in existence as of December 31, 1975, i.e., the universe of $\mathrm{mi}$ nority banks. The key advantage of an intragroup comparison is that uncontrollable differences between groups are neutralized to the greatest extent possible. At points in the analysis where a benchmark would be useful, however, reference will be made to standards maintained by commercial banks generally.

There are a number of possible ways to segment minority banks into groups for comparative purposes. As already mentioned, several previous studies [3,14] have emphasized age of operation and type of charter. Other possible selection criteria include location, size, and perhaps even racial composition. Using nonfinancial criteria as a basis for sample selection, however, involves inherent bias. The problem is that the use of such nonfinancial criteria involves a presupposition that the chosen basis for sample selection is in fact a critical determinant of operating performance. The dangers inherent in this approach are avoided here by concentrating on strictly financial characteristics as a guide to selecting minority bank groups for comparison.

Two groups of banks are selected from the universe, with a four-year consolidated return on investment (CROI) as the critical selection factor. Return on investment is used because of its importance as a basic performance index in the eyes of both financial analysts and private investors. A four-year consolidation procedure is followed in order to insure that the banks selected for the comparison groups, hereafter re- 
ferred to as the "high-earning" and the "residual" groups, have demonstrated earnings performance that can be considered sustainable over time. ${ }^{2}$ The period of consolidation includes the years 1972-75.

Of the 81 minority banks in existence as of December $31,1975,45$ had been in operation at least four years or longer. Thus, the universe of banks available for selection based on a four-year consolidation automatically is reduced from 81 to 45. In addition, one of the 45 banks is further eliminated due to its basic lack of conformity with the rest of the banks making up the universe. $^{3}$ The comparison groups, therefore, are chosen from among these 44 remaining minority banks.

2 Sustainability implies some degree of stability, too. A coefficient of variation (i.e., the standard deviation of nOI divided by the mean) has been computed for each of the 11 banks in the highearning group, with a resulting range of 0.11 to $0.6 \%$. Based on only four years of performance data, these coefficients are not suspiciously large. In addition, the variation is being measured around high mean vaiues of Ror.

3 This bank has been owned by minoxity stockholders for only 5 of its 20 years of existence. It had total assets at December 31,1975 , of $\$ 133$ million, placing it far beyond the normal size range of the remaining minority banks.
The cutoft point for a CROI that places a bank in the high-earning category is set at 10 percent, a commonly used rule for evaluating business performance. On this basis, 11 of the 44 banks are selected for the high-earning group. These banks are listed in Table $\mathrm{I}$. The remaining 33 banks constitute the residual group.

Nonfinancial Characteristics As Table I shows, the high-earning banks constitute a fairly diverse group. Nine of the eleven ( 82 percent) are blackowned, while 25 of the 33 residual banks ( 76 percent) are black-owned. As is also the case for the residual banks, most of the high-earning banks are located in large metropolitan areas, although the Northeast is conspicuously absent (three of the banks in the residual group are located in the New York City area, while one is located in Boston). Three of the high-earning banks, however, are located in cities with populations less than 100,000 . In terms of total assets at year-end 1975 , the high-earning banks range in size from $\$ 8.3$ million to $\$ 56.3$ million, the mean size being $\$ 26.5$ million. The residual banks have a smaller

Table I

\section{ELEVEN HIGH-EARNING MINORITY BANKS ${ }^{1}$}

\begin{tabular}{|c|c|c|c|c|c|}
\hline Bank Name & Location & $\begin{array}{l}\text { Charter Class and } \\
\text { Federal Reserve } \\
\text { Membership Status }\end{array}$ & $\begin{array}{l}\text { Establishment } \\
\text { Date }\end{array}$ & $\begin{array}{l}\text { Total Assets } \\
12-3 i-75 \\
\$ \text { Thousands }\end{array}$ & $\begin{array}{c}\text { Minority } \\
\text { Type } \\
\end{array}$ \\
\hline $\begin{array}{l}\text { Industrial Bank of } \\
\text { Washington }\end{array}$ & Washington, D. C. & State nonmember & $8-18-34$ & 40,082 & Black \\
\hline $\begin{array}{l}\text { United National Bank of } \\
\text { Washington }\end{array}$ & Washington, D. C. & National & $8-31-64$ & 30,846 & Black \\
\hline $\begin{array}{l}\text { Mechanics \& Farmers } \\
\text { Bank }\end{array}$ & Durham, N. C. & State nonmember & $3-1-08$ & 41,199 & Black \\
\hline First State Bank & Danville, Va. & State nonmember & $9-8-18$ & 8,340 & Black \\
\hline $\begin{array}{l}\text { Highland Community } \\
\text { Bank }\end{array}$ & Chicago, III. & State nonmember & $11-9-70$ & 21,063 & Black \\
\hline South Side Bank? & Chicago, III. & State member & 1.7 .72 & 20,024 & Black \\
\hline Centinel Bank & Taos, N. M. & State nonmember & $1-5-69$ & 11,636 & $\begin{array}{l}\text { Hispanic- } \\
\text { American }\end{array}$ \\
\hline Riverside National Bank & Houston, Tex. & National & $8-16-63$ & 12,974 & Black \\
\hline Bank of Finance & Los Angeles, Calif. & State nonmember & $11-16-64$ & 39,032 & Black \\
\hline Cathay Bank & Los Angeles, Calif. & State nonmember & $4-19-62$ & 56,317 & $\begin{array}{l}\text { Chinese- } \\
\text { American }\end{array}$ \\
\hline Liberty Bank of Seattle & Seattle, Wash. & State nonmember & $5-31.68$ & 10,485 & Black \\
\hline
\end{tabular}

'Banks with four-year consolidated return on investment of 10 percent or betfer.

"Minority shareholders gained controlling interest 5-1-72. 
mean size of $\$ 18.7$ million, with a range of $\$ 4.5$ million to $\$ 62.4$ million. While the average size high-earning group bank is about 40 percent larger than the average size residual group bank, there is nonetheless no simple association between larger size and higher profits. Indeed, 4 of the 11 high-earning banks fall below the average size of the residual group banks, and the operating economies enjoyed by a $\$ 26$ million bank over an $\$ 18$ million bank are certainly not great.

Eight of the high-earning banks (73 percent) are state nonmember banks, 2 are national banks, and only 1 is a state member bank. Among the residual banks, on the other hand, 19 (57 percent) are state nonmember banks, 13 (41 percent) are national banks, and, again, there is but one state member bank. This breakdown seems particularly interesting in view of the well-known argument that membership in the Federal Reserve System is a relatively costly alternative to nonmembership, inasmuch as reserve balances held with the Federal Reserve Banks are noninterest bearing. Although the high-earning banks, and to a lesser extent the residual banks, favor state charters and nonmember status in the Federal Reserve System, it should be pointed out that this pattern is changing somewhat. It will be recalled that 36 of the 81 minority banks in existence at year-end 1975 were not included in the final selection process, inasmuch as they were not in operation for four years or more. Of these 36 newer banks, 23 have national charters, 12 are state nonmembers, and 1 is a state member. ${ }^{4}$ The shift in interest to national bank charters is probably related to the liberalized application procedure toward minority banks adopted by the Comptroller of the Currency in the early 1970's.

With respect to age, the high-earning and residual banks are quite similar. The mean ages for the two groups are, respectively, 21 and 16 years. Both groups can be considered mature from the standpoint of experience and market representation. As Table I shows, the variation in age among the high-earning banks is considerable; 2 of the banks date from 1970, while 3 were established prior to World War II.

Financial Characteristics Both the high-earning group and the residual group have an eclectic makeup, but their overall nonfinancial characteristics are not that dissimilar. Inasmuch as this

- One of these 36 banks, a Mexican-American nationally chartered institution, failed in 1976. is the case, it would seem that there is a good possibility that earnings differentials are essentially the result of management differences. Such differences would appear on bank balance sheets and income statements, and it is the purpose of: this section to examine and compare important financial ratios for the two groups. As will become clear below, balance sheet management does indeed explain the success of the highearning group.

Capital Position Table II provides a summary of the capital positions of the high-earning and residual minority bank groups. The high-earning group, as the table illustrates, is somewhat less heavily capitalized than the residual group for each of the two measures shown. Interestingly, the same measures computed for all commercial banks in the U. S. on a four-year consolidated basis fall above the summary ratios for equity capital and reserves and between the summary ratios for total capital accounts. For all commercial banks, equity capital and reserves as a percent of risk assets is 8.4, while total capital accounts as a percent of risk assets is 9.0.

The comparison group of 11 high-earning minority banks has been selected on the basis of return on investment, and the possibility exists that some of these banks could have achieved a high return by sacrificing capital adequacy. For the group, this is not necessarily the case. At 7.5 , the ratio of equity capital and reserves to risk assets is below that of all commercial banks and the residual minority bank group, but is not extremely different. As the capital adequacy ranges show, there is a great deal of variability between banks within groups; this is especially

Table II

\section{CAPITAL POSITION}

\begin{tabular}{|c|c|c|}
\hline \multicolumn{3}{|c|}{ Four-Year Consolidation } \\
\hline Measure & $\begin{array}{c}\text { Eleven } \\
\text { High-Earning } \\
\end{array}$ & $\begin{array}{c}\text { Thirty-three } \\
\text { Residual }\end{array}$ \\
\hline \multicolumn{3}{|c|}{$\begin{array}{l}\text { Equity capital and reserves/ } \\
\text { Risk assets }\end{array}$} \\
\hline Group & 7.5 & 8.2 \\
\hline Range within group & 4.3 to 11.7 & 2.6 to 29.6 \\
\hline \multicolumn{3}{|c|}{ Total capital account/Risk assets 1} \\
\hline Group & 8.0 & 9.7 \\
\hline Range within group & 5.0 to 11.7 & 2.0 to 29.6 \\
\hline
\end{tabular}


true within the residual group. Only one bank in the high-earning group, whose capital ratios show up as the bottom end of the ranges in Table II, is seriously undercapitalized. Conversely, none of the high-earning banks is seriously overcapitalized. There are several overcapitalized banks within the residual group, however.

Sources of Funds At first glance, there appears to be a great deal of similarity regarding the types of deposits that provide the minority banks in the two groups with their major source of funds. As Table III indicates, total demand deposits as a percent of total liabilities for the high-earning and residual groups equals, respectively, 41.3 and 43.3 . The respective percentages for total time and savings deposits to total liabilities are 55.7 and 51.7. These ratios suggest that the residual group is in a relatively more advantageous position than the high-earning group, inasmuch as low-cost demand deposits comprise a larger proportion of the balance sheet and high-cost time and savings deposits comprise a smaller proportion. A closer inspection, however, suggests that this apparent relative advantage in favor of the residual bank group is more than outweighed by other adverse factors.

While the residual group does enjoy a slightly greater proportion of demand deposits to total liabilities than the high-earning group, a fairly large share of these demand deposits is in the form of liabilities to governmental bodies. Only 63.4 percent of the demand deposits of the residual group is due to private accounts, as compared to 77.0 percent for the high-earning group. This has several implications. First, government deposits are encumbered in the sense that they limit a bank's ability to allocate funds to the various available uses; these deposits must be secured by holdings of U. S. Treasury, or municipal, securities. Second, large holdings of governmental deposits relative to private deposits may reflect a special dependence on such a source of funds. To the extent that it does, it means that a bank may be overly protected and less inclined to compete for private business. This, clearly, is an undesirable long-run situation. The residual group is a heavier holder of U. S. Government (20.4 versus 15.0 percent) demand deposits, and of state and local (8.4 versus 3.6) demand deposits, as a proportion of total demand deposits.

The advantage to the residual group evidenced by its lower dependence on time and savings deposits is, again, more apparent than real. As in
Table III

\section{SOURCES OF FUNDS}

\begin{tabular}{|c|c|c|}
\hline \multicolumn{3}{|c|}{ Selected Categories, Four-Year Consolidation } \\
\hline Measure & $\begin{array}{c}\text { Eleven } \\
\text { High-Earning } \\
\end{array}$ & $\begin{array}{l}\text { Thirty-three } \\
\text { Residual }\end{array}$ \\
\hline $\begin{array}{l}\text { Total demand deposits/ } \\
\text { Total liabilities }\end{array}$ & 41.3 & 43.3 \\
\hline $\begin{array}{l}\text { IPC demand deposits/ } \\
\text { Total demand deposits }\end{array}$ & 77.0 & 63.4 \\
\hline $\begin{array}{l}\text { U. S. Government demand deposits } \\
\text { Total demand deposits }\end{array}$ & its/ 15.0 & 20.4 \\
\hline $\begin{array}{l}\text { Demand deposits of states and loe } \\
\text { gov./Tatal demand deposits }\end{array}$ & 3.6 & 8.4 \\
\hline $\begin{array}{l}\text { Total time and savings deposits/ } \\
\text { Total liabilities }\end{array}$ & 55.7 & 51.7 \\
\hline $\begin{array}{l}\text { IPC time deposits/ } \\
\text { Total time and savings deposits }\end{array}$ & 30.7 & 34.9 \\
\hline $\begin{array}{l}\text { Savings deposits/ } \\
\text { Total time and savings deposits }\end{array}$ & 56.8 & 43.0 \\
\hline $\begin{array}{l}\text { U. S. Government time deposits/ } \\
\text { Total time and savings deposits }\end{array}$ & 2.1 & 4.0 \\
\hline $\begin{array}{l}\text { Time deposits of states and local } \\
\text { gov./Total time and savings } \\
\text { deposits }\end{array}$ & 9.8 & 18.8 \\
\hline $\begin{array}{l}\text { Large denomination time deposits } \\
\text { (over } \$ 100,000) / \text { Total time and } \\
\text { savings deposits }\end{array}$ & 10.2 & 16.0 \\
\hline $\begin{array}{l}\text { Federal funds purchases/ } \\
\text { Total liabilities }\end{array}$ & 0.6 & 0.9 \\
\hline
\end{tabular}

the case of demand deposits, the residual bank group holds a greater proportion of U. S. Government, and state and local, time deposits to total time and savings deposits than does the highearning group. More importantly, however, savings deposits account for a much lower proportion of total time and savings deposits for the residual group ( 43.0 percent) than for the highearning group (56.8 percent). Savings accounts, of course, are traditionally viewed as being the most stable and, in the long run, relatively low cost, form of deposits. Their strength on a bank balance sheet also suggests a high degree of market penetration for consumer business. It could be argued that the benefits accruing from large savings deposit balances are offset to some degree by the higher activity levels, and thus higher costs, associated with these balances. These costs are largely recoverable, however, by the imposition of service charges tied to account activity levels.

The residual group does display a clear advantage over the high-earning group with respect to solicitation of private time deposits. Private time deposits as a percent of total time and savings deposits equals 34.9 for the residual group versus 
30.7 for the high-earning group. This may reflect a greater aggressiveness on the part of banks within the residual group to bid for large denomination deposits. The ratio of such deposits (those greater than $\$ 100,000$ ) to total time and savings deposits is 16.0 for the residual group and only 10.2 for the high-earning group.

Both comparison groups exhibit a very low dependence on purchases of Federal funds as a source of funds, as evidenced by their ratios of Federal funds purchased to total liabilities. Reliance on borrowed funds is also extremely low for both groups and is, therefore, not even shown in Table III.

Uses of Funds Table IV summarizes uses of funds for the two groups of minority banks. It is immediately evident that there exist a number of major differences between groups. To start with, it seems as if the residual group places a higher premium on portfolio liquidity than does the high-earning group. Cash balances and deposits at other commercial banks as a percent of total assets equals 11.9 and 10.1 for the residual and high-earning groups, respectively. Also, the residual group allocates a much greater share of funds to holdings of U. S. Treasury securities and a somewhat greater share to holdings of securities issued by $\mathrm{U}$. S. Government agencies.

Table IV

\section{USES OF FUNDS}

\begin{tabular}{|c|c|c|}
\hline \multicolumn{3}{|c|}{ Selected Categories, Four-Year Consolidation } \\
\hline Measure & $\begin{array}{c}\text { Eleven } \\
\text { High-Earning } \\
\end{array}$ & $\begin{array}{l}\text { Thirty-three } \\
\text { Residual }\end{array}$ \\
\hline $\begin{array}{l}\text { Cash and due from banks/ } \\
\text { Total assets }\end{array}$ & 10.1 & 11.9 \\
\hline $\begin{array}{l}\text { U. S. Treasury securities/ } \\
\text { Total assets }\end{array}$ & 9.9 & 12.6 \\
\hline $\begin{array}{l}\text { Obligations of U.S. Government } \\
\text { agencies/Total assets }\end{array}$ & 12.0 & 12.4 \\
\hline $\begin{array}{l}\text { Obligations of states and local } \\
\text { government/Total assets }\end{array}$ & 11.2 & 5.8 \\
\hline Federal funds sold/Total assets & 5.6 & 7.0 \\
\hline Other loans/Total assefs & 45.4 & 42.4 \\
\hline Real estate loans/Other loans & 48.8 & 29.9 \\
\hline $\begin{array}{l}\text { Single-family real estate loans/ } \\
\text { Real estate loans }\end{array}$ & 61.1 & 65.4 \\
\hline $\begin{array}{l}\text { Loans to financial institutions/ } \\
\text { Other loans }\end{array}$ & 0.5 & 2.8 \\
\hline $\begin{array}{l}\text { Commercial and industrial loans/ } \\
\text { Other loans }\end{array}$ & 26.3 & 38.2 \\
\hline Loans to individuals/Other loans & 22.7 & 27.5 \\
\hline $\begin{array}{l}\text { Credit card loans/ } \\
\text { Loans to individuals }\end{array}$ & 1.9 & 1.0 \\
\hline Bank premises/Total assets & 2.1 & 3.1 \\
\hline
\end{tabular}

A very significant difference in the asset portfolios of the two groups arises in the case of municipal investments. At 11.2 percent, the ratio of state and local government securities to total assets for the high-earning group is almost double the 5.8 percent of the residual group. This suggests that the high-earning group is much more sensitive to the need for sheltering income and that, as is the case for commercial banks generally, tax-free municipal securities provide an important avenue for this.

Sales of Federal funds, as a percent of total assets, equal 5.6 for the high-earning group and 7.0 for the residual group. This probably is a further indication of the higher priority given liquidity and security by the residual group. It may also, however, reflect the attractiveness of higher Federal funds yields in recent years. A highly liquid bank is able to shift into Federal funds sales much more readily than the less liquid bank. Rates on Federal funds are very volatile, however, and ease of investment in Federal funcls is hardly a good reason for maintaining an extremely liquid balance sheet. High earnings in one investment period can easily be offset in subsequent periods of generally increased banking system liquidity and lower interest rates.

The high-earning and residual groups devote about an equal amount of resources to loans; the ratio of other loans to total assets for the two groups is 45.4 and 42.4 , respectively. These ratios lie in what may be considered a very conservative range, so far as bank performance generally is concerned, and provide evidence that both groups are essentially conservative users of available funds. Although the high-earning and residual groups seem to take roughly the same approach to managing total loans as a proportion of total assets, they are not at all similar regarding the types of loans made. While the high-earning group is much more heavily committed to real estate lending, the residual group is much more oriented to business and consumer lending.

Real estate loans (or all loans secured primarily by real estate), account for 48.8 percent of total other loans (i.e., all loans excluding Federal funds sold and securities purchased under agreements to resell) made by the high-earning group, but only 29.9 percent for the residual group. To the extent that they make real estate loans, both groups are heavily oriented to single-family mortgage loans, probably the most secure type of real estate loan that can be made. The high-earning group is generally in a better position to make 


\section{Table V}

\section{EXPENSES}

Selected Categories, four-Year Consolidation

$\begin{array}{lcc}\text { Measure } & \begin{array}{c}\text { Eleven } \\ \text { High-Earning }\end{array} & \begin{array}{c}\text { Thirty-three } \\ \text { Residual }\end{array} \\ \begin{array}{l}\text { As a percent of total } \\ \text { operating expense: }\end{array} & & \\ \begin{array}{l}\text { Employee salaries, wages, } \\ \text { and benefits }\end{array} & 27.3 & \\ \text { Interest paid on deposits } & 41.3 & \\ \text { Net oceupancy expense } & 4.7 & 34.8 \\ \text { Furniture and equipment } & 2.7 & 5.4 \\ \text { Provisions for loan losses } & 5.3 & 2.9 \\ \text { Other operating expense } & 17.2 & \\ \text { Total operating expense/Total assets } & 6.2 & 18.9 \\ \end{array}$

real estate loans, being able to match this longterm use of funds with a large base of stable savings deposits.

The residual bank group makes up for its much lower relative involvement in real estate lending by activity in other areas. The residual group, for example, makes 2.8 percent of total other loans to other financial institutions, versus 0.5 percent for the high-earning group. More important, however, is the heavy degree of involvement by the residual group in business lending, with 38.2 percent of total other loans falling in the commercial and industrial category, versus only 26.3 percent for the high-earning group. This is an especially important finding in view of the fact that minority banking has been thought of as a special source of capital to the minority business community [12]. Clearly, the high-earning group has decided that the risks inherent in minority business lending, which have been shown to be significant [15], are so great as to be avoided to a fairly extreme degree. The cautious approach taken by the high-earning group toward lending to minority businesses has recently been articulated by the president of one of the eleven banks within the group. ${ }^{5}$ In this instance, it is pointed out that minority banks take a more cautious approach toward lending in the minority business community than many majority banks.

In the area of consumer lending, the residual group is again significantly more active than the high-earning group. The ratios of loans to individuals to total other loans for the two minority bank groups are 27.5 and 22.7 , respectively. Again, the high-earning group seems to have

"Joseph D. Hutnyan, "Minority Banker Warns Some Banks Overeatrer on Minority Lending," American Banker, May 12, 1976. adopted management policies designed to minimize its involvement in a more risky area of lending. While both groups have a low level of participation in revolving credit to consumers, the high-earning group is almost twice as active in this specialized area.

Before leaving the asset side of the balance sheet, it is interesting to note the extent to which bank funds are tied up in investment in bank premises. At 2.1 percent, the ratio of bank premises to total assets for the high-earning group is about one-third less than the 3.1 percent of the residual group. This means, in effect, that the high-earning group operates with considerably less overhead than does the residual group, and the funds freed ap from investment in fixed assets can be applied to earning uses. Both groups, it might be mentioned, have a greater investment in fixed assets than is typically the case in the banking industry. All insured commercial banks, on a four-year consolidated basis, have a bank premises to total assets ratio of 1.6 percent, and all banks with less than $\$ 50$ million in assets have a ratio of 1.7 .

Expenses and Income Tables V and VI summarize, respectively, the expense and income characteristics of the high-earning and residual groups. In briet, the high-earning group is shown to be more efficient with regard to both control of

Table VI

INCOME

Selected Categories, Four-Year Consolidation

\begin{tabular}{|c|c|c|}
\hline Measure & $\begin{array}{l}\text { Eleven } \\
\text { gh-Earning }\end{array}$ & $\begin{array}{c}\text { Thirty-three } \\
\text { Residual }\end{array}$ \\
\hline \multicolumn{3}{|l|}{$\begin{array}{l}\text { As a percent of total } \\
\text { operating income: }\end{array}$} \\
\hline Interest and fees on loans & 53.3 & 52.2 \\
\hline Income on Federol funds sold & 7.5 & 8.3 \\
\hline Trust department income & 1.5 & 1.4 \\
\hline Service charge income & 7.8 & 8.5 \\
\hline Other operating income & 1.2 & 2.1 \\
\hline $\begin{array}{l}\text { Inferest and dividends on } \\
\text { investments }\end{array}$ & 30.0 & 28.4 \\
\hline \multicolumn{3}{|l|}{$\begin{array}{l}\text { As a percent of interest and dividends } \\
\text { on investments }\end{array}$} \\
\hline Income on U. S. Treasury securities & 31.9 & 38.2 \\
\hline $\begin{array}{l}\text { Income on obligations of } U . S \text {. } \\
\text { Government agencies }\end{array}$ & 35.8 & 42.0 \\
\hline $\begin{array}{l}\text { Income on obligations of states and } \\
\text { local governments }\end{array}$ & 23.0 & 12.8 \\
\hline Total operating income/Total assets & 7.0 & 6.8 \\
\hline $\begin{array}{l}\text { Operating income - operating expense } \\
\text { Total cssets }\end{array}$ & 0.8 & $-0 . i$ \\
\hline $\begin{array}{l}\text { Net income/Equity capital } \\
\text { and reserves }\end{array}$ & 12.6 & -2.3 \\
\hline
\end{tabular}


expenses and generation of income. This conclusion is based on the total operating expense to total asset and total operating income to total asset ratios shown in the tables. The high-earning group incurs expenses equal to 6.2 percent of total assets and generates income equal to 7.0 percent of total assets; its spread of gross income over expenses amounts to 0.8 percent of total assets. The residual group incurs expenses equal to 6.9 percent of total assets and generates income equal to 6.8 percent of total assets. In the case of the residual bank group, therefore, expenses exceed gross income, and an operating loss equal to 0.1 percent of total assets results. For comparative purposes it is interesting to note that for all insured commercial banks the spread of gross income over expenses, on a four-year consolidated basis, amounts to 1.0 percent of total assets. While generating less income in relation to total assets than the high-earning group, at 6.6 percent, expenses to total assets for all insured commercial banks is also much lower, at 5.6 percent.

These basic indexes of management performance ultimately, of course, affect the profitability of the two groups, as shown in Table VI. Consolidated return on investment for the highearning group is a very respectable 12.6 percent, while that for the residual group is -2.3 percent.

An analysis of group expenses provides a way of detcrmining the nature of the differences between the high-earning and residual groups on this important factor leading to CROI. Both groups devote an almost equal proportion of total operating expense (keeping in mind that their operating expense as a proportion of total assets differs) to employee remuneration; the percentages are 27.3 for the high-earning group and 27.2 for the residual group. This is the second most important expense item in the commercial banking industry, and the equality between groups suggests that the labor market conditions they face are about equal. Interest expense on deposits is the biggest banking industry expense and, as the source of funds analysis undertaken above would suggest, the high-earning group allocates a much greater proportion of total expense to this category. This is due to the highearning group's heavier reliance on time and savings deposits as a source of funds.

Previous analysis also suggests that overhead expenses for the high-earning group should be less than those for the residual group, and this turns out to be the case. Net occupancy expense for the high-earning group is only 4.7 percent of total expenses, as compared to 5.4 percent for the residual group. Equipment expense for the highearning group is also a somewhat lower proportion of total expenses than for the residual group, at 2.7 and 2.9 percent, respectively.

Loan loss provisions, which are treated as a current operating expense, are significantly different for the two groups. Such provisions amount to only 5.3 percent of total expenses for the high-earning group, but increase to 9.2 percent for the residual group. This one expense category is so high for the residual group as to almost eliminate the advantage it has due to low deposit costs. The high loan loss expense is, most likely, associated with the higher proportions of business and consumer loans made by the residual group. It is interesting to note that the four-year consolidated loan loss expense for all insured commercial banks is 4.2 percent, considerably below that of even the high-earning group.

Interest and fees on loans as a percent of total operating income for the two groups is roughly the same, at 53.3 percent for the high-earning group and 52.2 percent for the residual group. This, however, is not what one would expect given the composition of their loan portfolios. The high-earning group is relatively heavily invested in illiquid, but relatively low risk, real estate loans. Conversely, the residual group is relatively heavily invested in more risky business and consumer loans. If, as would be expected, the residual bank group were compensated for the increase in risk associated with its business and consumer lending, then such a premium would be reflected in higher interest income on loans. This is clearly not the case. Both groups have about the same proportion of income derived from loan interest and, while their total loan portfolios equal about the same percentage of assets, the risk distribution is quite different. The residual group should be charging higher interest rates on loans in order to compensate for the additional risk, which is reflected in its higher expense for loan losses. In practice, however, the rate of return on loan portfolio (computed from interest and fees on loans/total other loans) is almost identical for the two groups. The rates of return on loan portfolio for the high-earning and residual groups are, respectively, 8.26 percent and 8.33 percent.

In a number of other respects, the income sources for the two groups are similar. Both derive a fairly large share of income from Federal 
funds sales, something characteristic of smaller banks generally. Likewise, their service charge income is fairly high, although it is more so for the residual group. Trust department income makes a very minor contribution to total income.

Interest and dividends earned on investments represents 30.0 percent of total operating income for the high-earning group and 28.4 percent for the residual group. These proportions are close but, as in the case of loans, disguise important differences of portiolio composition. The residual group is relatively heavily invested in U. S. Treasury securities and relatively under invested in municipal securities, while the converse is true for the high-earning group. Thus, the residual group derives 80.2 percent of its investment income from the taxable yields off $U$. S. Treasury and U. S. Government agency securities, and only 12.8 percent off nontaxable municipal securities. The high-earning group derives 67.7 percent of its investment income from U. S. Treasury and $U$. S. Government agency securities, and 23.0 percent from municipal securities.

The importance of tax management differences between the two groups cannot be overemphasized. The high-earning group has managed its tax position in such a way as to minimize applicable corporate income taxes; indeed, its applicable income taxes as a percent of gross income equals only 20.5 percent. For the residual group, an unusual result is obtained. It will be recalled that this group has sustained an income loss over the four-year consolidation; nonetheless, the group has still paid corporate income taxes equal to 30.4 percent of its losses. This contradictory situation is explained by the fact that the members of the group have had different tax and earning experiences, some earning no income and paying no tax and some paying tax on earned income. Also, the tax and earnings data are consolidated over a four-year period, allowing yearly income period fluctuations to show up in the final figures.

The high-earning group, incidentally, has been able to achieve its status without paying out an excessive proportion of net income in dividends. Cash dividends paid by the high-earning group amounts to a conservative 28.4 percent of net income. This means that a significant portion of earnings has been retained and added to reserve accounts. The residual group has paid cash dividends equal to 35.1 percent of its losses; this anomalous situation is explained by the consoli- dation process described above in the context of tax payments.

Summary and Conclusions In this study, minority-owned commercial banks with four years or more operating experience are divided in to two comparison groups according to earnings performance. Those banks with a four-year consolidated return on investment of 10 percent or better constitute the high-earning group, while the renaining banks with a four-year consolidated return on investment of less than 10 percent are combined into a residual group. The performance of the high-earning group is compared with that of the residual group through an analysis of key operating ratios.

The indings indicate that the high-earning group is somewhat more adept at generating income than is the residual group; total operating incone to total assets is 7.0 for the high-earning group and 6.8 for the residual group. On the other hand, the high-earning group is much more effective at controlling expenses than the residual group, the respective ratios of total operating expense to total assets being 6.2 and 6.9. Consequently, the high-earning group has an excess of operating income over operating expense equal to 0.8 percent of total assets, compared to an excess of operating expense over operating income of 0.1 percent for the residual group. Both groups invest a fairly low proportion of funds, about 45 percent, in loans. The types of loans made, however, are quite different between groups; real estate loans dominate the portfolio of the highearning group, and commercial and industrial loans dominate the portfolio of the residual group. With respect to securities, the highearning group favors tax-free municipals while the residual group favors $U$. S. Treasury securities. Employee remuneration accounts for 27 percent of total expenses for both groups. Interest paid on deposits is a much higher expense for the high-earning group, which relies to a greater extent on time and savings deposits than does the residual group. This higher expense item for the high-eaming group is offset by lower occupancy and loam loss charges and by lower general operating expenses. The management practices followed allow the high-earning group to achieve a four-year consolidated return on investment of 12.6 percent, compared with a loss of 2.3 percent for the residual group. 
These findings can be synthesized into two basic conclusions about minority banks. First, there exist a variety of circumstances under which minority banks can successfully operate; this is suggested by the heterogeneous nature of the high-earning group. Although such factors as size, location, type of charter, etc may, and probably do influence bank operation, they do not dictate success or failure. Rather, quality of financial management appears to be the critical determinant of minority bank performance.

Second, there appears to be a direct conflict between market exigencies faced by minority banks generally, for example the need to correctly assess and balance risk and return on loans, and the idealized set of community service goals under which minority banks are often conceived. This conflict is most evident in the differences between the loan policies of the high-earning and residual groups. The high-earning group has clearly chosen to forego some lending opportunities, particularly in the business and consumer loan areas, due to what is evidently viewed as excessive risk. The residual group has been much more active in making business and consumer loans in the minority community but has suffered from unusually large losses. It is largely the relative success in limiting the expense of losses associated with bad loans that provides the high-earning group with its margin of performance over the residual group. While many minority banks choose to follow the typical path of success laid out by nonminority banks, particularly in making high proportions of business loans, the loan portfolio of the high-earning group definitely reflects a concern with the special risk that might be connected with this type of lending in the minority community. It would seem, therefore, that successful banking in the minority community requires very careful attention to asset quality and may not be wholly compatable with the capital demands of minority business.

The high-earning group is, in a number of important ways, more like majority-owned and operated commercial banks than like the residual group. For example, the high-earning group is more competitive and market oriented than the residual group, as evidenced by its deposit structure. It is more conscious of operating efficiency, as shown through key expense ratios. And, not least important, the high-earning group seems more adept at practicing the subtieties of financial management than the residual group; evidence of this is provided by the tax management practices of the two groups. More interesting, though, is the fact that the high-earning group does more than simply copy the portfolio behavior of successful nonminority banks. Rather, it applies the practice of accepted management patterns to fit the special environment in which it operates, thus achieving financial success.

\section{References}

1. Ang, James and Richard Willhour. "The Consumer Loan Supply Function of a Minority Bank: An Empirical Note." Joumal of Money, Credit and Banking, (May 1976), pp. 255-9.

2. Boorman, John T. New Minority-Owned Commercial Banks: A Comparative Analysis. Washington, D. C.: Federal Deposit Insurance Corporation, 1973.

3. "The Prospects for Minority-Owned Commercial Banks: A Comparative Performance Analysis." Journal of Bank Research, (Winter 1974), pp. 263-79.

4. and Myron L. Kwast. "The Start-Up Experience of Minority-Owned Commercial Banks: A Comparative Analysis." Journal of Finance, (September 1974), pp. 1123-41.

5. Brimmer, Andrew F. "The Negro in the National Economy." The American Negro Reference Book. Edited by John P. Davis. Englewood Cliffs, New Jersey: Prentice Hall, Inc., 1966.

6. "The Banking System and Urban Economic Development." Paper presented before a joint session of the 1968 Annual Meetings of the American Real Estate and Urban Economics Association and the American Finance Association, Chicago, Illinois, December 28, 1968.

7. "The Black Banks: An Assessment of Performance and Prospects." Joumal of Finance, (May 1971), pp. 379-405.

8. 1 "Recent Developments in Black Banking: 1970-1971," Washington, D. C., July 31, 1972. (Mimeographed.)

9. Corwin, R. D. Racial Minorities in Banking: New Workers in the Banking Industry. New Haven: College \& University Press, 1971.

10. Emeka, Mauris Lee Porter. Black Banks, Past and Present. Kansas City: Mauris L. P. Emeka, 1971.

11. Irons, Edward D. "Black Banking-Problems and Prospects." Journal of Finance, (May 1971), pp. 407-25.

12. Knight, Kenneth E. and Terry Dorsey. "Capital Problems in Minority Business Development: A Critical Analysis." American Economic Review, (May 1976), pp. 328-31.

13. Kohn, Donald L. "Minority Owned Banks." Monthly Review, Federal Reserve Bank of Kansas City, (February 1972), pp. 11-20.

14. Leavitt, Brentin C. "Black Banks: A Review of Earnings Performance." Address before the First Annual Director-Senior Management Seminar of the National Bankers Association, Inc., Atlanta, Georgia, July 21, 1972.

15. Marsh, James. "Viewing the Loss Experience on Minority Enterprise Loans." Bankers Magazine, (Winter 1971), pp. 84-7.

16. Thieblot, Armond J., Jr. The Negro in the Banking Industry. Philadelphia: Industrial Research Unit, Wharton School of Finance and Commerce, University of Pennsylvania, 1970.

17. Walker, Charles E. Address before the 43rd Annual Convention of the National Bankers Association, St. Louis, Missouri, October 16, 1970. Reprinted in the Department of the Treasury News, Washington, D. C. 


\title{
A MONETARIST MODEL OF WORLD INFLATION AND THE BALANCE OF PAYMENTS
}

\author{
Thomas M. Humphrey
}

The inflation of the past ten years has been a worldwide phenomenon. Accordingly, analysts have become increasingly aware that any satisfactory explanation of price level behavior must account for its international character. These analysts fall into three main schools. First are the eclectics, who attribute world inflation to a complex and ever-changing mixture of causes, e.g., the exercise of monopoly power by oil-producing nations; the international conjuncture of cyclical booms; and the occurrence of bad harvests, poor fish catches, and other autonomous reductions in the supplies of key commodities. Second are the members of the cost-push school, who blame inflation on worldwide labor militancy. Third are the global monetarists, who, in sharp contrast with the other schools, focus largely or exclusively on the monetary factor.

The theoretical basis of this third approach is the monetary theory of the balance of payments. As usually presented, this theory assumes that the countries of the world are linked together (as they actually were until 1973) by fixed exchange rates between freely convertible currencies. The sum total of these currencies converted into a common unit at the fixed exchange rate constitutes the world money stock. This stock, in conjunction with the demand for it, determines the world price level, which is then transmitted to individual countries by commodity arbitrage, the operation of which tends to equalize prices in all markets. Finally, by importing or exporting money in exchange for goods and securities, each nation uses the mechanism of the balance of payments to bring its domestic money stock into line with the exact quantity required to support the price level. When applied to the interpretation of recent inflationary experience-at least up to 1973 when fixed rates were widely abandoned for flexible ones - this theory implics that excessive world monetary expansion generated the inflation, that commodity arbitrage propagated it, and that the balance of payments mechanism listributed the world money supply as required to accommodate or validate it in each nation.
This articie seeks to explain the foregoing theory and its public policy implications with the aid of a simple expository model of the international monetary mechanism. Although originally constructed for the specific purpose of analyzing the economic effects of a currency devaluation, the model is easily adaptable to the monetarist explanation of world inflation. ${ }^{1}$ In fact, it constitutes an aimost ideal framework within which to articulate the global monetarist view because it embodies most of the elements essential to that view. These elements are outlined in the following section, which serves as a necessary preliminary to the cescription of the model and its components.

Monetarist Propositions Any analytical model that conveys the essence of the global monetarist explanation of world inflation must contain certain key ingredients that characterize that approach. These elements include the following:

1. THE VIEW OF THE WORLD AS THE RELEVANT CLOSED ECONOMY. The global monetarist views the world as a closed system of interdependent open national economies connected by fixed or imperfectly floating exchange rates. In this view, nations are interpreted as regions of the closed world economy, and problems of inflation in any particular nation are treated as purely regional phenomena, as are questions relating to an individual nation's distributive share of the world money stock.

2. THE QCANTITY THEORY OF MONEY. The quantity theory constitutes the second key component of the global monetarist view. The quantity theory states that the path of world prices in longrun equilibrium is completely determined by the path of the world money stock. This conclusion follows from the theory of the interaction between the demand for real (price-deflated) money balances and the nominal stock of money. The demand for real balances is interpreted as a stable mathematical function of a few macroeconomic variables, the most important being real income and an inter-

\footnotetext{
The model is presented by Dornbusch in [3]. See Mundell [4, Chapter 8: 5, Chapters 9, 10,11, 12, 15] for an earlier and somewhat different treatment of the main elements of the model. The most complete description of the Dornbusch model appears in Whitman [7], who uses it to explain the global monetarist approach to the balance of payments. Swoboda [6] and Claassen [2] employ the Dornbusch model to analyze world inflation under fixed and flexible exchange rates, respcctively. Also see Branson [1] for a similar approach. The present article follows Whitman and Swobodit closely.
} 
est rate variable representing the opportunity cost of holding money. Given the values of these independent variables, the theory states that the price level will adjust to bring the real volume of any nominal stock of money into equality with the amount demanded. From this it follows that if the income and interest rate determinants of the demand for money are given, an exogenously given nominal stock of money completely determines the price level. More generally, in terms of a growing world economy, the long-run rate of world monetary expansion determines the steady-state rate of world inflation, given the trend growth rate of world output. Two important implications of the quantity theory should be noted at this point. The first is that money has no influence on real economic variables in the long run. The second is that in long-run equilibrium the price level will vary in exactly the same proportion as the money stock. Known as the neutrality and equiproportionality postulates, respectively, these two propositions must be embodied in any mathematical model that purports to represent the logical structure of the global monetarist view.

3. LAW OF ONE PRICE. From the universally accepted proposition that commodity arbitrage tends to equalize prices of identical traded goods across countries-due allowance of course being made for tariffs and transportation costs-monetarists move directly to the proposition that general price levels also tend to be equalized. Monetarists note that in a world of rigidly fixed exchange rates between freely convertible currencies money itself becomes a homogeneous traded good whose price, like that of any other traded good, will be equalized internationally. But since the domestic price of money in terms of goods is simply the inverse of the general price level, it follows that equalization of the price of money implies equalization of national price levels. This point, incidentally, distinguishes modern global monetarists from their classical counterparts of the $18 \mathrm{th}$ and $19 \mathrm{th}$ centuries, notably David Hume and David Ricardo. The latter group argued that the volume of imports and exports depends on domestic prices relative to foreign prices and that changes in these relative prices constitute a key link in the automatic specieflow mechanism that operates to correct payments imbalances and to maintain the equilibrium international distribution of the precious metals. Modern monetarists deemphasize such relative price effects on the grounds (1) that efficient arbitrage prevents price disparities from developing except for the briefest of intervals and (2) that the automatic adjustment process operates mainly through divergences between income and expenditure rather than through the classical relative price mechanism.

4. MONETARY INTERPRETATION OF THE BALANCE OF PAYMENTS. The fourth key component of the monetarist approach is the concept of the balance of payments as the means by which open economies adjust their existing stocks of money to the stocks they desire to hold. Suppose a country's actual money stock is smaller than the stock its residents desire to hold. Endeavoring to replenish their cash balances, these residents will cut their expenditure thereby releasing resources for the export trade. The country will run a trade balance surplus, exporting goods and importing money until the gap between actual and desired money stocks is eliminated. Conversely, if the existing stock of money is greater than that desired, national expenditure will exceed national output and the country will run a trade balance deficit, importing goods and exporting money until the excess money balances are worked off. In this manner, each nation will use its balance of payments to attain monetary equilibrium, and for the world as a whole, the balance of payments mechanism will distribute the world money stock across nations consistent with monetary equilibrium in each nation. The key assumption underlying the foregoing view is that, in the long run at least, national central banks do not use open market operations and other policy weapons to offset or neutralize ("sterilize") the impact of external money flows on the behavior of the domestic money stock. One justification for this assumption is that the effect of sterilization operations would be to create international interest rate differentials that would induce capital flows sufficient to undermine the sterilization policy. Finally, it should be noted that the nonsterilization assumption means that from the point of view of an individual country the money supply is an endogenous variable completely determined by the public's decisions to acquire or get rid of cash through the balance of payments. Here the traditional monetarist assumption of an exogenous money stock applies only to the closed world economy and not to individual open national economies.

Constituting the essential ingredients of the monetarist theory of world inflation, these four elements are incorporated in the analytical model presented below.

The Model and Its Components The model itself consists of a hypothetical two-country world economy represented by a set of equations containing the following variables. Let $D$ be the desired stock of national nominal money balances and $M$ the actual stock composed of a domestic credit component $C$ and an international reserve component $R$. Furthermore, let $\dot{M}$ and $\dot{R}$ be the rates of change (time derivatives) of the national money stock and its foreign exchange reserve component, respectively, and $\mathrm{A}$ be an adjustment coefficient representing the speed of adjustment of actual to desired money stocks. Also, let $\mathrm{K}$ be the desired ratio of nominal cash balances to nominal income, $Y$ the level of real output, $P$ the price level, and $X$ the exchange rate (domestic currency price of a unit of foreign currency). The cash balance ratio $K$ is treated as a numer:- 
cal constant, and the output and exchange rate variables are taken as exogenously-determined givens. Finally, let $\mathrm{E}$ be nominal national expenditure and $B$ the trade balance measured in domestic currency. For simplicity, the trade balance is identified with the overall balance of payments, i.e., the capital account and international capital flows are ignored. Unstarred variables refer to the home country, starred variables to the foreign country (i.e., rest of the world), and the subscript $w$ to the closed world economy. Percentage rates of change of variables are represcnted by lower-case letters-for example, $p$ is the percentage rate of change of the price level $P$.

Purchasing Power Parity Equation The first equation of the model is the goods arbitrage or purchasing power parity equation

\section{(1) $\mathrm{P}=\mathrm{XP} *$}

which embodies the "law of one price" proposition that international arbitrage tends to equalize the money price of goods in terms of either currency. The equation states that the price level in the home country is equal to the product of the exchange rate and the price level in the foreign country, implying that the price levels in the two countries are the same when converted into a common unit at the fixed exchange rate. Note that this equation corresponds to the global monetarist view that national commodity markets are merely parts of a single unified world commodity market.

Money Demand Equations The second part of the model consists of demand for money equations, one for each country. These equations express the stock of nominal money balances that the public desires to hold in the aggregate as a constant fraction $\mathrm{K}$ of the level of nominal national income (the product of the price level and the exogenously given level of real output). The equations are written as follows:

$$
\mathrm{D}=\mathrm{KPY} \text { and } \mathrm{D}^{*}=\mathrm{K} * \mathrm{P}^{*} \mathrm{Y}^{*} \text {. }
$$

As written, these demand functions comply with the quantity theory of money in at least three respects. First, the exogeneity of the real output variable squares with the quantity theory's assumption that output is determined independently of the behavior of money in the long run. Second, the demand functions exhibit a one-to-one relationship between the quantity of money demanded and the price level. In the technical jargon of monetary theory, the functions are said to be homogeneous of degree one in prices. This homogeneity property implies both (1) absence of money illusion (the inability of economic agents to distinguish between real and nominal economic magnitudes) and (2) longrun neutrality of money as postulated by the quantity theory. It also ensures that the theory's equiproportionality postulate will be satisfied, i.e., that the price level will vary in exactly the same proportion as the money supply. Third, the demand functions exhibit the stability required by the theory, this stability being assured by the assumed constancy of the desired money/ income ratios.

Money Supply Equations The foregoing demand equations represent only one side of the money market and must be matched by supply equations representing the other. These equations are derived from the consolidated balance sheet of the commercial banks and the central bank of each country. By a simple accounting identity, the monetary liabilities of those sectors can be shown to be backed by an equivalent amount of assets as indicated by the equations

$$
\text { (3) } M=C+R \text { and } M^{*}=C^{*}+R^{*} \text {. }
$$

Here $M$ is the narrowly defined money supply (currency plus demand deposits), $\mathrm{C}$ is domestic credit defined as the banking system's holdings of net domestic assets, and $\mathrm{R}$ is the banking system's holdings of international reserves. The foregoing equations merely express national money stocks as the sum of their respective source components, domestic and foreign. Of these two components only the first is under the control of the monetary authority. By contrast, the foreign source component-and therefore the money stock itself-is determined by the public's demand for cash. If the public is just satisfied to hold the existing stock of money, any policyengineered change in the domestic credit component will induce an equal but opposite change in the foreign source component, leaving the nation's money stock unchanged.

Corresponding to the national money supply equations is the equation

$$
\text { (4) } \mathrm{M}_{w}=\mathrm{M}+\mathrm{XM} *
$$

that defines the world money stock $M_{w}$ as the sum of the national money stocks expressed in a common currency unit. The world money stock 
is treated as an exogenous variable. This follows from the assumption that the quantity of world reserves is given. Given the latter, all the components of the world money stock, namely the domestic source component of the national money stocks plus world reserves, are exogenous and therefore so is the world money stock itself. Note, however, that while total world reserves can be treated as a given, a single nation's reserve holdings cannot be so treated, which is the reason national money supplies are endogenous variables from the viewpoint of the national authorities. Despite their simplicity, equations 3 and 4 are taken as constituting an accurate specification of the supply side of the money market.

Money market equilibrium, of course, requires that money demand equal money supply in each nation, implying a zero excess demand for money. Although this condition must be satisfied in the long run, it may well be violated in the short run, in which case national money markets will exhibit temporary disequilibrium as manifested by excess demands for or supplies of money. When monetary disequilibrium occurs, however, an automatic self-corrective mechanism starts to function as people begin to adjust their cash holdings to bring actual liquidity back into line with desired liquidity.

Money Stock Adjustment Equations The adjustment mechanism mentioned in the preceding paragraph is represented by the model's fifth set of equations, which state that the rate at which each country augments or depletes its cash holdings is proportional to the excess demand for money. These money stock adjustment equations are written as follows:

(5) $\dot{M}=A(D-M)$ and $\dot{M}^{*}=A^{*}\left(D^{*}-M^{*}\right)$,

where $\dot{M}$ is the change in money holdings per unit of time, $\mathrm{D}-\mathrm{M}$ is excess demand for money (the difference between desired and actual stocks), and $A$ is an adjustment coefficient expressing the speed at which money stocks are adjusted in response to excess demand. The closer the coefficient is to unity the faster the adjustment, and the closer it is to zero the slower the adjustment. In the extreme case where the coefficient has a numerical value of unity, adjustment is sufficiently rapid to eliminate excess stock demand within the same period it occurs. In the opposite case, i.e., a zero coefficient, adjustment never occurs and excess demand persists indefinitely. The model assumes that the coefficient is large enough to insure that full stock adjustment is eventually achieved. The channel or mechanism through which monetary adjustment is accomplished is, of course, the balance of payments.

Balance of Payments Equation The sixth component of the model is the balance of payments equation, which performs two important functions. First, it specifies the role of the external trade balance in the money stock adjustment process. Specifically, the equation states that the trade balance surplus (the excess of money receipts from sales abroad over monetary expenditures on purchases from abroad) is by definition equal to the country's net change in international reserves and therefore, given domestic credit, in the stock of money itself, i.e., $B=\dot{R}=\dot{M}$. This expression corresponds to the monetary theory of the balance of payments according to which a nation adds to its stock of money by running a trade balance surplus, exporting goods in exchange for money, and reduces its money stock by running a trade deficit, importing goods in exchange for exports of money. The expression also embodies the key monetarist assumption that the policy authorities do not offset or nullify ("sterilize") the impact of payments disequilibria and reserve flows on the domestic money supply.

The second purpose of the equation is to insure that the two-country model is internally consistent by imposing the condition that, for the world as a whole, the sum of the individual trade balances when measured in terms of a common, monetary unit is identically equal to zero. This condition means that if the home country is running a trade balance surplus, the foreign country (rest of world) must be running a trade deficit of the same amount when measured in terms of home country currency. Symbolically, the balance of payments identity is $B=-X^{*}$, where $B$ is the home country's trade balance surplus and $-\mathrm{XB}^{*}$ is the foreign country's trade deficit (a negative surplus) expressed in units of domestic currency at the fixed exchange rate. This expression, showing how the individual countries are unified via the balance of payments identity, constitutes a mathematical statement of the global monetarist view of the world as a closed system of interdependent open economies.

To summarize, the complete balance of payments equation, expressing both the zero world trade balance identity and the monetary view of the external accounts, is written as follows: 
(6)

$$
\begin{aligned}
\mathrm{B}= & -\mathrm{XB}^{*}=\dot{\mathrm{M}}=\dot{\mathrm{R}}=-\mathrm{X}_{\mathrm{M}^{*}}= \\
& -\dot{\mathrm{X}}^{*} .
\end{aligned}
$$

Note that since by definition the foreign country's trade deficit measured in terms of domestic currency must equal the home country's surplus, it follows that the money outflow from the former country must also equal the money inflow into the latter. Here is the global monetarist view of the balance of payments as the allocation mechanism that distributes a given total of world money across nations.

Expenditure Equations Completing the model are the expenditure equations that describe the connection between the money market and the commodity market. These equations indicate that in a world in which the public can hold only money and/or goods, an excess demand for one implies a corresponding excess supply of the other and vice versa. Written as follows:

$$
\text { (7) } \mathrm{E}=\mathrm{PY}-\dot{\mathrm{M}} \text { and } \mathrm{E}^{*}=\mathrm{P}^{*} \mathrm{Y}^{*}-\dot{\mathrm{M}}^{*} \text {, }
$$

the equations express a relationship between domestic expenditure $E$ (i.e., spending by domestic residents on both home- and foreign-produced goods), nominal income $P Y$, and the rate of accumulation or decumulation of cash balances $\dot{\mathrm{M}}$.

According to the equations, spending equals income only when cash balances are not being augmented or depleted, i.e., when the public is just satisfied to hold the existing stock of money. An excess supply or demand for money, however, causes expenditure to deviate from income. For example, an excess demand for cash means that commodity expenditure falls short of income as the public endeavors to build up its cash balance. Conversely, an excess supply of money implies that expenditure exceeds income as the community tries to get rid of its excess cash holdings. Note also that the equations imply a relationship between spending, income, and the trade balance. This corresponds to the monetarist view that the international adjustment process operates primarily through divergences between expenditure and income rather than through changes in the relative prices of exports and imports. The equations imply that when domestic spending for goods exceeds domestic income (production), net commodity imports will fill the gap and the trade balance will be in deficit. Similarly, when domestic expenditure falls short of production, the unabsorbed output will be exported, thereby re- sulting in a trade surplus. Only if expenditure just equals production will the trade balance be zero.

The Equations Summarized Taken together, the foregoing equations embody the main elements of the monetarist view of the world economy. The equations link the levels of prices, expenditures, and desired and actual money stocks in the two countries as well as the flows of money and goods between them. To summarize, the equations are written as follows:

(1) $\mathrm{P}=\mathrm{XP} *$

(2) $\mathrm{D}=\mathrm{KPY} \quad \mathrm{D} *=\mathrm{K} * \mathrm{P} * \mathrm{Y} *$

(3) $\mathrm{M}=\mathrm{C}+\mathrm{R} \quad \mathrm{M}^{*}=\mathrm{C}^{*}+\mathrm{R}^{*}$

(4) $M_{w}=M+X M$

(5) $\dot{M}=A(D-M) \quad \dot{M}^{*}=A^{*}\left(D^{*}-M^{*}\right)$

(6) $\mathrm{B}=-\mathrm{XB}^{*}=\dot{\mathrm{M}}=\dot{\mathrm{R}}=-\mathrm{X}^{*}=$ $-\mathrm{X} \dot{\mathrm{R}}^{*}$

(7) $\mathrm{E}=\mathrm{PY}-\dot{\mathrm{M}} \quad \mathrm{E}^{*}=\mathrm{P}^{*} \mathrm{Y}^{*}-\dot{\mathrm{M}} *$.

Equations $1-4$ help determine the equilibrium (steady-state) values of the price and monetary variables, while equations 5-7 describe the adjustment mechanism by which equilibrium is restored following a monetary disturbance. Specifically, the equilibrium world price level is determined by equating the world money supply shown in equation 4 with the aggregate world real demand for money implicit in equation 2 . Once determined, the world price level is then transmitted to the two countries via commodity arbitrage as described in equation 1 . The resulting country price levels enter equation 2 to determine nominal national demands for money. If these latter variables differ from the existing national money stocks shown in equation 3, the discrepancy enters equation 5 to determine the rate of money stock adjustment, which enters equations 6 and 7 to determine national expenditures, trade balances, and the corresponding international redistribution of the world money stock.

Less formaliy, the model implies the following causal chain:

1. The world stock of money determines the world price level.

2. International arbitrage brings national prices into equality with world prices.

3. National price levels determine national nominal demands for money. 
4. National money demands in conjunction with national money supplies determine the rate of money stock adjustment.

5. Money stock adjustment determines spending, trade balances, and the direction and volume of international money flows.

6. This process continues until the equilibrium international distribution of money is achieved, and money market equilibrium is restored in each country. At this point the system is said to be in steady-state equilibrium.

Long-Run Steady-State Solution of the System In any economic system, the long-run steadystate is characterized by full stock equilibrium, i.e., a situation in which existing asset stocks just equal desired asset stocks. In the hypothetical system described by the model, steady-state equilibrium occurs when the existing stock of money (the sole asset) equals the desired stock. As can been seen from equations 5 through 7 , this in turn implies that money stock adjustment, trade balances, and the gap between expenditure and income are all zero. In long-run equilibrium, therefore, equations 5 through 7 are irrelevant, and one can analyze the determination of world prices and their rate of inflation from the first four equations alone.

World Price Level and Inflation Rate A central proposition of global monetarism is that, under a regime of fixed exchange rates, the steady-state path of world prices is determined by the path of the world money stock. A version of the quantity theory of money, this proposition can be demonstrated with the aid of the four equations relevant to the analysis of long-run equilibrium.

The demonstration requires several steps. First, impose the condition of stock equilibrium and set the supplies of money equal to demands, e.g., $M=K P Y$. Second, use the fixed exchange rate to express the money stock and price variables as world-level magnitudes. As defined in equation 4 , the world money stock is the sum of the national money stocks measured in terms of a single currency, i.e., $M_{w}=M+X M^{*}$. Similarly, by virtue of the purchasing power parity assumption, each nation's price level expressed in terms of a common unit is equal to the world price level, i.e., $P_{w}=P=X P *$. Note that the assumption of a fixed exchange rate is absolutely indispensable here since it provides the invariable common unit required to convert national variables into a single homogeneous world-level measure that has analytical significance. ${ }^{2}$ The third step is to recognize that by choice of an appropriate unit of measurement for either currency the exchange rate can be set equal to unity, thus permitting the relationship between the world money stock and the world price level to be written simply as $\mathrm{M}_{\mathrm{w}}=\mathrm{M}+\mathrm{M}^{*}=(\mathrm{KY}+$ $\left.\mathrm{K}^{*} \mathrm{Y}^{*}\right) \mathrm{P}_{\mathrm{w}}$. In long-run equilibrium, the variables enclosed by parentheses are regarded as exogenously determined by tastes, technology, and resource endowments, and consequently are taken as given. It follows, therefore, that, in terms of the model, the world price level is fully determined in the long run by the world money stock, with changes in the latter variable causing equiproportionate changes in the former.

Corresponding to the preceding equilibrium money-price relationship is the equilibrium distribution of the world money stock. The home country's natural proportional share or fraction $S$ of world money can be expressed as $S=$ $\mathrm{M} / \mathrm{M}_{\mathrm{w}}=\mathrm{KY} /\left(\mathrm{KY}+\mathrm{K}^{*} \mathrm{Y}^{*}\right)$, and similarly for the other country (rest of world), whose share, of course, is $1-S$. This important result states that, in steady-state equilibrium, the fraction of world money distributed to each nation depends upon the relative importance of the nation's demand for real cash balances as compared with the demands of the entire world. The demand for real balances, of course, is expressed as the product of the desired money/income ratio and real income. Assuming both countries have identical money/income ratios, the country with the greater real income will command the lion's share of the world money stock. As shown below, the distributive share parameters $S$ and $1-S$ appear in the expression for the world rate of inflation, the derivation of which constitutes the final step of the demonstration.

The expression for the world rate of inflation is derived by taking the time derivative of the logarithm of the world money-price level relationship and is written as $\mathrm{p}_{\mathrm{w}}=\mathrm{m}_{\mathrm{w}}-[\mathrm{Sy}+$ (1-S) $\left.y^{*}\right]^{3}$ Here $p_{w}$ is the percentage rate of world inflation, $\mathrm{m}_{\mathrm{w}}$ is the percentage rate of growth of the world money stock, $y$ and $y^{*}$ are the exogenously given trend growth rates of real output in the two countries, and $S$ and $1-S$ are the shares of each country in the world money

$\approx$ A flexible exchange rate implies two distinct national money stocks and price levels separated by a variable exchange rate relationship between them, and therefore precludes any meaningfui concept of a single world money stock and worid price level. 3 Note that the derivation of this formula requires that the model be
reinterpreted to allow for steady-state growth of the relevant varireinterpreted to allow for sieady-state growth of the relevant vari-
ables. Accordingly, the equilibrium magnitudes of the variables are expressed not as absoiute dollar levels but rather as constant percentage rates of change. 
stock. This equation states that the rate of world inflation is equal to the difference between the world rate of monetary expansion and the growth rate of world output as measured by the sum of the weighted national output growth rates, the weights being the countries' shares in the world money supply. In short, the equation is an exact statement of the monetarist conclusion that inflation results when world monetary expansion outpaces world output growth.

The Dynamic Adjustment Process So much for the determination of the path of world prices in steady-state equilibrium. The next stage of the analysis deals with the international adjustment mechanism as described in equations 5 through 7 . Regarding the adjustment process, three questions are especially pertinent. First, what responses are provoked by an autonomous increase in the domestic money supply of a single open economy? Second, how do these responses raise the world price level? Third, how do individual countries subsequently adjust to the higher world price level?

To answer these questions, start from a hypothetical situation of worldwide monetary equilibrium, and let this equilibrium be disturbed by a monetary expansion in the home country. According to the model, this disturbance generates an excess supply of money leading to a trade balance deficit and an excess home demand for goods in the world commodity market, putting upward pressure on world prices. The resulting world price increase, disseminated abroad via the international arbitrage mechanism, induces corresponding changes of opposite sign in the demandfor-money, stock-adjustment, expenditure, and trade-balance equations of the foreign country." Adjustment continues until both monetary redundancy in the one country and monetary deficiency in the other are eliminated. When equilibrium is restored, world and national price levels will have risen in proportion to the rise in the world money supply.

The preceding corresponds closely to the monetarist interpretation of the worldwide inflation of the late 1960's and early 1970's. According to this view, excessive monetary expansion in the

The rise in world prices also affects the home country, reducing but not eliminating the excess supply of money there. This latter result follows from the fact that world prices rise in proportion to the world, not the national, money stock. Since the home country's stock is but a fraction of the world stock, a given percentage change in the former corresponds to a smaller percentage change in the latter, and therefore in the world price level. In short, world prices will not rise sufficiently to eliminate the initial excess supply of money in the home country. The redundant money must be gotten rid of through the balance of payments.
U. S. generated a persistent excess demand for goods and consequently a series of balance of payments deficits that pumped dollars into the international monetary system in sufficient quantities to contribute significantly to global inflation. This view departs from the model only in one key respect. It contends that, because the dollar itself constituted the primary international reserve asset, the $U$. S. was able to engage in domestic credit expansion that led to the inflationary rise in world liquidity without suffering a loss of its own reserves. Lacking an external reserve constraint, the U. S., in this view, became a potentially potent source of world inflation.

Policy Implications of the Model The model described in the preceding paragraphs contains some radical implications for economic stabilization policy. These implications can be classified according to whether they pertain to small or to large open economies. Small economies are those whose domestic policy actions can be treated as having a negligible impact on the rest of the world. Large economies, by contrast, are those whose policies have a significant global influence. In some cases-e.g., the United States-an economy may be so large as to warrant interpretation as a closed economy. In what follows it is also well to remember that the often unconventional conclusions derived from the model reflect the particular assumptions underlying it, and that many of these assumptions are open to serious criticism. This is especially true of the assumptions of (1) full employment, (2) perfect international arbitrage, (3) exogeneity of real income, (4) nonsterilization of international money flows, and (5) the existence of an inherently stable selfregulating world economy. While these assumptions may hold in long-run equilibrium, empirical evidence suggests that they may not hold over any realistic current policy-making horizon nor over the transitional adjustment period following monetary shocks. Recognition of this fact would certainly modify-perhaps drastically-any policy prescriptions based on the model. Subject to these caveats, the policy implications of the model are summarized below.

Small Country Implications The first and most radical implication stemming from the model is that, in the case of small open economies operating with fixed exchange rates, traditional macroeconomic monetary and balance of payments policies are both unnecessary and useless. They are 
unnecessary because the international adjustment mechanism works automatically to correct economic disequilibria and to provide each country with sufficient money to accommodate full capacity levels of output. They are useless because the domestic authorities cannot control the money supply or the balance of payments, both of which are endogenous variables determined by the public's demand for money.

Suppose, for example, the authorities try to improve the country's balance of payments by devaluing the currency, i.e., engineering a onetime increase in the pegged exchange rate. This devaluation has no permanent impact on the trade balance. There is, to be sure, a favorable short-run impact, but this impact is inherently transient as can be seen by tracing the sequence of events triggered by the policy action. First, the devaluation causes a step increase in the exchange rate. Given the foreign price level, however, the home price level must immediately rise in the same proportion as the exchange rate to preserve purchasing power parity. The domestic price increase raises the stock of cash balances demanded by the public. This generates an excess demand for money, leading to a reduction in expenditure and to a trade balance surplus. The surplus, however, is short-lived, since it is accompanied by an inflow of money that eventually eliminates the discrepancy between actual and desired cash balances. When this happens, the adjustment process ceases, domestic spending again equals production, and the trade balance surplus vanishes. The sole long-run effect of the devaluation is on the price level which, according to the demand for money equation, rises in exact proportion to the increase in the domestic money supply. Within the context of the example, the authorities are powerless to exercise permanent control over the balance of payments.

The only thing the monetary authorities can control in a small open economy is the composition of the money supply, i.e., the mix between domestic credit and international reserves. They cannot, however, govern the size or total quantity of the money supply. For according to the monetary theory of the balance of payments, an expansion in the controllable domestic credit component of the money stock will result in a balance of payments deficit and an outflow of the uncontrollable international reserve component until the money stock returns to its initial level. When equilibrium is restored, the mix of the money stock will be changed-domestic credit having displaced international reserves dollar for dollar -but the total will be unaltered. This conclusion follows directly from the model as can be seen by setting the money supply equation equal to the money demand equation to yield $C+R=K P Y$. Given the long-run equilibrium values of the variables on the right-hand side of this equation, it follows that any change in the domestic credit component $\mathrm{C}$ must be offset by a change identical in size but opposite in sign in the international reserve component $\mathrm{R}$ to keep the total money stock equal to the unchanged steady-state demand for it. In short, the total stock of money is no more a controllable variable than is the balance of payments in a small open economy.

A second policy implication is that, assuming the absence of monetary contraction abroad, a nation's monetary authorities are solely to blame for its balance of payments deficits, since there can be no deficits unless there is an excess supply of money. It should be noted, however, that such deficits are inherently transitory phenomena. For the model predicts that they will vanish as soon as the redundant money is diffused throughout the world economy by the operation of the international adjustment mechanism.

A third policy implication is that, in a world of fixed exchange rates, a small open economy can control neither its price level nor its rate of inflation, since both are determined in world markets. This means that an individual country will find it impossible to avoid inflating at the world rate. It also means that in a iixed exchange rate system all national inflation rates must eventually converge. This latter conclusion can be demonstrated by taking the time derivative of the logarithm of the purchasing power parity equation. This operation yields the result $p=x+p^{*}$ where $p$ and $p^{*}$ are the percentage rates of price inflation in the home and foreign country, respectively, and $x$ is the percentage rate of change of the exchange rate. This result states that rates of inflation in the home country and the rest of the world can differ only by the proportional rate of change of the exchange rate. In a system of fixed exchange rates, however, the latter variable is zero and therefore the two inflation rates must converge. In short, with iixed exchange rates, countries cannot continually inflate at different rates.

A fourth policy implication, therefore, is that if a country wishes to choose its own inflation rate independent of the rest of the world it must operate with a flexible exchange rate. $\mathrm{By}$ 
letting its currency float, a country can gain control over its money supply and hence its rate of inflation. The logic behind this conclusion is straightforward. Floating exchange rates operate to maintain continuous equilibrium in a country's external accounts, thereby obviating the need for international money flows. It follows, therefore, that increases in the domestic money stock, instead of being diffused abroad through the balance of payments, will remain at home to induce equiproportional rises in the domestic price level. Note that the adjustment mechanism in the floating rate case differs markedly from that of a fixed rate regime. In the latter, money market equilibrium is restored by quantity adjustments, namely, international flows of money. In the former case, however, stock equilibrium is restored by price adjustments, namely, changes in the domestic price levels. To summarize, with the exchange rate floating so as to equilibrate the balance of payments, a nation's money stock becomes an exogenous variable which the authorities can control to achieve any rate of inflation they desire.

If a floating exchange rate permits a country to determine its own rate of inflation, then it also insulates that country from inflation originating abroad. Thus when a foreign nation inflates its money supply while the home country holds its currency constant, the resulting rise in the foreign price level will be offset by an equiproportional fall in the exchange rate, leaving domestic prices unchanged. Note, however, that this conclusion has an important corollary, namely, that under a flexible exchange rate a country must suffer the full consequences of its inflationary policies since it cannot export its inflation abroad.

It would be wrong to conclude from the above arguments that monetarists believe that flexible exchange rates are inherently superior to fixed rates. On the contrary, many monetarists are opposed to floating rates for at least two reasons. First, floating rates eliminate the risk-pooling and efficiency advantages of international money associated with fixed rates. Second, volatile exchange rates between currencies would tend to reduce the effectiveness of money as a social institution for economizing on the use of scarce resources in the production and dissemination of economic information.

It is on the basis of such arguments that some monetarists-e.g., Robert A. Mundell and Arthur Laffer-urge the restoration of a system of fixed exchange rates, with the rate of world monetary expansion being regulated by a world central bank. By contrast, other monetarists such as Milton Friedman, Harry G. Johnson, and David Laidler, while agreeing that volatile exchange rates introduce risk and inefficiency into the international economy, do not believe that a regime of institutionaliy fixed exchange rates is necessarily the best solution. According to these latter monetarists, floating rate volatility stems from domestic mone:ary policies that are erratic, variable, and divergent as between countries. This volatility, it is claimed, would be eliminated if all countries abandoned discretionary countercyclical monetary management for fixed monetary rules. The adoption of rules calling for a constant rate of domestic monetary expansion equal to the trend growth rate of real output supposedly would make the flexible rate virtually as stable as a rigidly fixed rate. Moreover, flexible rates have the added advantage of being determined by market forces, thus freeing governments to use their policy instruments in pursuit of purely domestic obiectives.

It is apparent from the above that while monetarists agree that exchange rate stability is necessary for an efficiently operating international economy, they disagree on the question of the most appropriate exchange rate regime. This disagreement is not as important as it appears, however, since all monetarists acknowledge that the key to exchange rate stability lies less in the way the foreign exchange market is organized than in finding a means of coordinating national monetary policies. True, the policy coordination problem has not been solved, although many solutions have been proposed (including the above-mentioned proposals of rules and a world central bank . But if and when it is solved, the exchange rate-whether fixed or floating-will be stable. And once the exchange rate is stabilized, inflation will again be an international rather than a national problem. This is because a stable rate of exchange between national currencies makes the sum of those currencies an economically relevant aggregate and also implies that national inflation rates will converge on a common (world) level.

Large Country Implications The policy implications discussed in the preceding paragraphs refer to small oper: economies. As pointed out earlier, however, the implications are substantially different when the individual country is large relative to the rest of the world. The main difference concerns the ability of a country to control its own 
inflation rate under a system of fixed exchange rates. As noted earlier, in a fixed rate regime an individual country's domestic monetary expansion will affect its price level only indirectly by influencing the world money supply and the world price level. The strength of this influence is in direct proportion to the relative economic size of the country as measured by its share of the world money supply. For an individual small country this share is negligible and therefore so is the country's ability to influence its own price level. In sharp contrast, a large country's money stock forms a substantial proportion of the world money stock such that an expansion in the former stock will result in a significant expansion in the latter and, therefore, in the world and national price levels. Because of its size, the large country is able to indirectly regulate its own money stock and price level even in a world of fixed exchange rates. In this sense, a large country's money stock becomes an exogenous variable and its price level an endogenous one, which is just the reverse of the case for small countries.

Apart from sheer size, there is a second reason why a large country may be able to control its money supply even in a fixed rate regime. The country may be a reserve currency country, i.e., one whose currency is held by other countries as a form of international reserves. As previously mentioned, in a fixed rate world with no reserve currency country, nations can control the composition but not the quantity of their individual money stocks. According to the monetary theory of the balance of payments, an expansion in the controllable domestic credit component of a nation's money stock will result in a balance of payments deficit and an outflow of the uncontrollable international reserve component until the money stock returns to its initial level.

In the case of a reserve currency country, however, an expansion in the domestic credit portion of the money supply need not lead to an offsetting contraction in the international reserve component if the rest of the world holds its increased reserves in the form of government securities issued by the reserve currency country. Although the country runs a balance of payments deficit as a result of its domestic monetary expansion, its status as a reserve currency country enables it to effectively neutralize the impact of the payments deficit on its money supply. Thus despite the deficit, the authority is able to achieve an expansion of the money supply. Apparently such was the case in the late 1960's and early 1970's when the reserve currency status of the dollar enabled the U. S. to expand its money stock in the face of large external deficits. This latter experience indicates that the reserve currency case constitutes an important exception to the monetarist prediction that payments deficits tend to be accompanied by reductions in the nation's money stock.

Summary This article has expounded the global monetarist explanation of inflation within the iramework of a simple two-country model that links national price levels, money stocks, money flows, spending, and the balance of payments. The model can account for the generation of world inflation under fixed exchange rates, for the transmission of that inflation to individual national economies, and for the distribution of world money necessary to support it in each nation. Typically monetarist, the model stresses the role of the demand for money in determining both the steady-state path of world prices and the dynamic adjustment to that path. The model also yields the standard predictions of the quantity theory, namely equiproportionality of money and prices, long-run neutrality of money, and the equilibrium international distribution of money. Moreover, it embodies the global monetarist conception of the international economy as a stable self-regulating mechanism in which monetary and payments disequilibria are inherently transitory phenomena. Finally, the model provides a iramework for stating clearly the macroeconomic policy problems confronting small open economies.

\section{References}

1. Branson, William H. "Monetarist and Keynesian Models of the Transmission of Inflation." American Economic Review, 65 (May 1975), 115-19.

2. Claassen, Emil M. "World Inflation Under Flexible Exchange Rates." Scandinavian Journal of Economics, 78, No. 2 (1976), 346-65.

3. Dornbusch, Rudiger. "Devaluation, Money, and Nontraded Goods." American Economic Review, 63 (December 1973), 871-80.

4. Mundell, Robert A. International Economics. New York: Macmillan, 1968.

5. - Monetary Theory: Inflation, Interest, and Growth in the World Economy. Pacific Palisades: Goodyear, 1971 .

6. Swoboda, Alexander $\mathrm{K}$. "Monetary Approaches to the Transmission and Generation of Worldwide Inflation." Geneva: Graduate Institute of International Studies, 1975. (Mimeographed.)

7. Whitman, Marina v.N. "Global Monetarism and the Monetary Approach to the Balance of Payments." Brookings Papers on Economic Activity, 6, No. 3 (1975), 491-536. 